\title{
KAJIAN PEMODELAN MATEMATIKA TERHADAP PENYEBARAN VIRUS AVIAN INFLUENZA TIPE-H5N1 PADA POPULASI UNGGAS
}

\author{
Dian Permana Putri' ${ }^{1}$, Herri Sulaiman² \\ ${ }^{\prime}$ FKIP, Pendidikan Matematika, Universitas Swadaya Gunung Jati Cirebon \\ ${ }^{2}$ FKIP, Pendidikan Matematika, Universitas Swadaya Gunung Jati Cirebon \\ e-mail:hs_msc@yahoo.com
}

\begin{abstract}
Abstrak. Seperti yang dikutip dari Centers of Disease Control and Prevention, Avian Influenza (Al), atau sering disebut dengan flu burung adalah penyakit menular yang disebabkan oleh virus H5N1 tipe A pada unggas. Virus H5N1 diklasifikasikan ke dalam dua kategori yaitu patogenik rendah dan patogenik tinggi yang mengacu pada kemampuan virus untuk menyebabkan penyakit parah (berdasarkan karakteristik molekuler dari virus dan mortalitas pada unggas di bawah kondisi percobaan). Virus H5N1 hidup dalam saluran pencernaan unggas sehingga unggas yang terinfeksi dapat mengeluarkan virus ini melalui tinja yang kemudian mengering dan hancur menjadi semacam bubuk. Bubuk inilah yang kemudian dihirup oleh manusia atau binatang lainnya. Pada penelitian ini, untuk mempresentasikan pola penyebaran virus Avian Influenza pada populasi unggas dibuat ke dalam bentuk model matematika dengan menggunakan Sistem Persamaan Diferensial Nonlinear (PDNL). Dari fakta yang ada mengenai virus Avian Influenza, dibentuk asumsi yang nantinya digunakan untuk membuat model matematika. Setelah model matematika terbentuk lebih lanjut dicari titik ekuilibrium model dan dianalisis apakah titik ekuilibrum yang ditemukan stabil asimtotik atau tidak, kemudian diakhir penelitian ditentukan simulasi numeris dengan membuat plot/grafik dari sistem model matematika agar dapat diinterpretasikan pada keadaan yang sebenarnya.
\end{abstract}

Kata kunci : Avian Influenza, Pemodelan Matematika, Titik Ekuilibrium, Kestabilan

\section{PENDAHULUAN}

Semakin berkembangnya ilmu pengetahuan dan ilmu pengobatan tidak menjamin manusia akan terbebas dari penyakit. Hal ini disebabkan karena penyakit dan virus juga semakin berkembang dan bermutasi sehingga kebal terhadap obat maupun antibiotik. Salah satu virus yang memiliki kemampuan bermutasi yang sangat cepat adalah virus yang bertipe-H5N1 yang selanjutnya dikenal dengan istilah virus H5N1. Penyakit flu burung atau Avian Influenza (AI) merupakan penyakit yang disebabkan oleh virus $\mathrm{H} 5 \mathrm{~N} 1$ yang biasa menyerang pada unggas. Virus $\mathrm{H} 5 \mathrm{~N} 1$ selain dapat menular dari unggas ke unggas ternyata dapat pula menular dari unggas ke manusia sehingga ketika wabah flu burung merebak, kepanikan massal dapat terjadi dimana-mana. Tingkat pengetahuan masyarakat yang rendah terhadap penyakit ini membuat banyak yang bereaksi dengan ekstrim. Tanpa pikir panjang, ratusan ribu unggas dimusnahkan, tanpa melihat efektifitas dari pemusnahan tersebut. Oleh karena itu ada baiknya lebih dikenal terlebih dahulu tentang karakteristik dari virus H5N1 ini. Seperti yang dikutip dari Centers of Disease Control and Prevention, Avian Influenza (AI), biasa disebut flu burung adalah penyakit menular yang disebabkan oleh virus H5N1 tipe A pada unggas. Virus H5N1 diklasifikasikan ke dalam dua kategori yaitu: patogenik rendah dan patogenik tinggi yang mengacu pada kemampuan virus untuk menyebabkan penyakit parah (berdasarkan karakteristik molekuler dari virus dan 
mortalitas pada unggas di bawah kondisi percobaan). Infeksi unggas oleh virus low pathogenic Avian Influenza (LPAI) tidak menyebabkan penyakit atau hanya menyebabkan penyakit ringan (seperti bulu rontok dan penurunan produksi telur pada unggas) dan tidak dapat dideteksi. Infeksi unggas oleh virus highly pathogenic Avian Influenza (HPAI) dapat menyebabkan penyakit berat dengan mortalitas (kematian) yang tinggi. Virus HPAI dan LPAI dapat menular dengan cepat melalui unggas. Infeksi virus HPAI pada unggas dapat menyebabkan penyakit yang mempengaruhi beberapa organ dengan rentang kematian hingga 90-100\% dan masa inkubasi 48 jam (World Health Organization). Ada perbedaan genetik dan antigenetik antara virus $\mathrm{H} 5 \mathrm{~N} 1$ subtipe virus yang biasanya hanya menginfeksi unggas dan yang dapat menginfeksi unggas dan manusia. Virus H5N1 tidak menyerang manusia hingga akhir tahun 1997, baru muncul kasus pertama seorang manusia terinfeksi virus $\mathrm{H} 5 \mathrm{~N} 1$ di Hongkong. Setelah itu, infeksi virus H5N1 pada manusia terjadi secara terus menerus. Diketahui sudah 133 orang terinfeksi di Asia pada akhir tahun 2003, 68 diantaranya meninggal dunia. HPAI menyebabkan tingkat kematian hingga $100 \%$ pada unggas dan lebih dari $70 \%$ pada manusia. Angka ini sangatlah tinggi mengingat tingkat kematian karena virus H5N1 pada 1918 hanya beberapa persen saja. Pada tanggal 1 April 2013, untuk pertama kalinya dilaporkan kasus infeksi varian baru virus flu burung H7N9 pada manusia. Infeksi ini dikaitkan dengan penyakit pernapasan parah dan kematian. Hal ini menunjukkan cepatnya mutasi pada virus H5N1. Virus H5N1 dapat menular ke manusia jika ada interaksi langsung dengan unggas yang terinfeksi. Virus H5N1 hidup dalam saluran pencernaan unggas sehingga unggas yang terinfeksi dapat mengeluarkan virus ini melalui tinja yang kemudian mengering dan hancur menjadi semacam bubuk. Bubuk inilah yang kemudian dihirup oleh manusia atau binatang lainnya. Menurut situs resmi WHO, virus $\mathrm{H} 5 \mathrm{~N} 1$ lebih mudah menular dari unggas ke manusia dibandingkan dari manusia ke manusia dan mungkin menular dari manusia ke manusia jika virus $\mathrm{H} 5 \mathrm{~N} 1$ sudah bercampur dengan selnya. Model matematika dari penularan virus $\mathrm{H} 5 \mathrm{~N} 1$ ini diperkenalkan untuk lebih memahami kompleksitas epidemiologi penyakit flu burung dan munculnya pandemi dari flu burung. Pada penelitian ini akan ditentukan analisis kualitatif dari model penularan virus H5N1 untuk mendapatkan bilangan reproduksi dasar $\mathrm{R}_{0}$, dimana $\mathrm{R}_{0}$ bertujuan untuk mengetahui adanya penularan penyakit atau tidak adanya penularan penyakit melalui analisis stabilitas dari titik ekuilibrium bebas penyakit maupun titik ekuilibrium endemik. Model matematika yang akan digunakan adalah model penularan virus $\mathrm{H} 5 \mathrm{~N} 1$ pada populasi unggas dengan menggunakan model SI. SI merupakan pengelompokan pada populasi unggas menjadi dua kompartemen yaitu unggas yang rentan dan unggas yang terinfeksi.

Pada penyebaran virus H5N1, populasi unggas dapat dibagi menjadi tiga kelas yaitu (1) unggas yang masuk ke dalam kelas rentan (susceptible) yaitu unggas yang sehat namun rentan terhadap virus $\mathrm{H} 5 \mathrm{~N} 1$ sehingga banyaknya unggas yang masuk ke dalam kelompok susceptible ini dapat dinyatakan dengan $S_{u}$. (2) Unggas yang masuk ke dalam kelas terinfeksi (infected) yaitu unggas yang telah terinfeksi dan dapat menularkan virus H5N1 kepada unggas lainnya, sehingga banyaknya unggas yang masuk ke dalam kelas terinfeksi (infected) ini dapat dinyatakan dengan $I_{u}$. Dengan demikian jumlah unggas yang berada di dalam populasi ini adalah $N_{u}=S_{u}+I_{u}$. Untuk mempermudah dalam membentuk diagram transfer dari sistem penyebaran virus $\mathrm{H} 5 \mathrm{~N} 1$ pada populasi unggas, maka akan dijelaskan terlebih dahulu siklus interaksi antara unggas 
yang rentan dengan unggas yang terinfeksi. Di dalam penelitian ini, diasumsikan bahwa laju kelahiran atau imigrasi pada populasi unggas dapat dinyatakan dengan $K_{u}$ dan dapat dikelompokkan ke dalam kelas rentan dengan proporsi dari $K_{u} \leq 1$. Pada awalnya, unggas yang berada di dalam kelas rentan itu berasal dari perkembangbiakan unggas (kelahiran), imigrasi (perpindahan) ataupun unggas yang telah menetap di alam bebas atau di suatu penangkaran/kandang. Lebih Lanjut, terdapat laju kematian alami dari unggas yaitu laju kematian tanpa terinfeksi virus $\mathrm{H} 5 \mathrm{NI}$ yang dinyatakan dengan $\mu_{u}$. Kemudian beberapa unggas yang berada di kelas rentan telah terjangkit/terinfeksi virus H5N1 dan menularkan virus ini ke unggas yang lain, sehingga populasi unggas yang berada di dalam kelas ini semakin meningkat, dengan demikian kelas ini disebut dengan kelas terinfeksi (infected). Perlu diketahui bahwa laju efektivitas penularan pada populasi unggas saat melakukan kontak dengan unggas terinfeksi dapat dinyatakan dengan $\beta_{u}$. Lebih lanjut, unggas yang terinfeksi virus akan mati sehingga laju kematian unggas akibat terinfeksi virus $\mathrm{H} 5 \mathrm{~N} 1$ dapat dinyatakan dengan $\alpha_{u}$. Di dalam penelitian ini, diasumsikan bahwa tidak ada populasi unggas yang sembuh dari serangan virus H5N1, karena mengingat umur unggas yang relatif singkat dan tingkat immunitas (kekebalan) dari tubuh unggas yang cukup lemah. Dengan demikian dari penjelasan di atas maka didapat diagram transfer untuk model penyebaran virus $\mathrm{H} 5 \mathrm{~N} 1$ pada populasi unggas sebagai berikut :

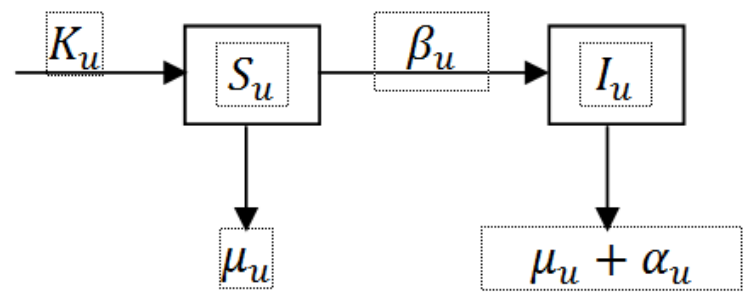

Gambar 4.1. Diagram transfer model penyebaran virus $\mathrm{H} 5 \mathrm{~N} 1$ pada populasi unggas

Dari gambar 4.1 di atas terlihat bahwa populasi unggas dibagi dalam dua kelas yaitu kelas rentan $\left(S_{u}\right)$ dan kelas terinfeksi $\left(I_{u}\right)$ yang mengacu pada model matematika epidemiologi SI. Berdasarkan asumsi-asumsi dan diagram transfer yang telah dibentuk, maka model matematika untuk penyebaran virus $\mathrm{H} 5 \mathrm{~N} 1$ pada populasi unggas dituliskan

\section{METODE PENELITIAN}

Penelitian mengenai model penularan virus $\mathrm{H} 5 \mathrm{~N} 1$ pada populasi Unggas diawali dengan studi literatur mengenai sifat-sifat dan karakteristik virus $\mathrm{H} 5 \mathrm{~N} 1$ kemudian disusun asumsi-asumsi berdasarkan kondisi sebenarnya seperti adanya laju kelahiran, dalam bentuk Persamaan Diferensial Nonlinear (PDNL) sebagai berikut :

$$
\begin{aligned}
\frac{d S_{u}}{d t} & =K_{u}-\left(\beta_{u} I_{u}+\mu_{u}\right) S_{u} \\
\frac{d I_{u}}{d t} & =\beta_{u} I_{u} S_{u}-\left(\mu_{u}+\alpha_{u}\right) I_{u} .
\end{aligned}
$$

\section{(4.1)}

dan diberikan nilai awal sebagai berikut :

$S_{u}(0)=\left(S_{u}\right)_{0}>0, I_{u}(0)=\left(I_{u}\right)_{0}>0$ dan diasumsikan untuk $K_{u}, \beta_{u}, \mu_{u}$ dan $\alpha_{u}>0$.

kematian, laju kontak populasi rentan dengan populasi terinfeksi, dan lain sebagainya. Dari fakta dan asumsi yang didapatkan maka dibentuk suatu diagram transfer dari penularan virus H5N1 pada populasi unggas. Setelah itu dibentuk model matematika yang mewakili diagram tersebut. Model 
matematika dalam penelitian ini merupakan Sistem Persamaan Diferensial Nonlinear. Dari sistem ini akan ditentukan titik ekuilibrium endemik dan titik ekuilibrium bebas penyakit dari populasi unggas. Linearisasi dari sistem nonlinear dilakukan untuk mempelajari solusi disekitar titik ekuilbrium karena sulit menemukan solusi eksak dari sistem nonlinear. Linearisasi dapat dilakukan dengan menggunakan matriks Jacobian kemudian sifat kestabilan titik ekuilibrium dapat dianalisis dari nilai eigen matriks Jacobian dari masing-masing

\section{HASIL PENELITIAN DAN PEMBAHASAN}

\section{Model Penyebaran Virus H5N1 Pada} Populasi Unggas

Berikut ini akan diberikan lemma yang membahas bahwa solusi dari Sistem (4.1) yang memenuhi kondisi awal $S_{u}(0)=$ $\left(S_{u}\right)_{0}>0, \quad I_{u}(0)=\left(I_{u}\right)_{0}>0 \quad$ bernilai positif.

\section{Lemma 4.1.1}

Jika $S_{u}(t)$ dan $I_{u}(t)$ adalah solusi pada Sistem (4.1) yang memenuhi kondisi awal $S_{u}(0)=\left(S_{u}\right)_{0}>0, \quad I_{u}(0)=\left(I_{u}\right)_{0}>0$ maka $S_{u}(t)$ dan $I_{u}(t)>0$.

\section{Bukti :}

Dari persamaan kedua pada Sistem (4.1) didapat :

$$
\frac{d I_{u}}{d t}=\beta_{u} I_{u} S_{u}-\left(\mu_{u}+\alpha_{u}\right) I_{u}
$$

jika kedua ruas pada Persamaan (4.2) diintegralkan akan didapat :

$$
\begin{aligned}
& \int \frac{d I_{u}}{I_{u}}=\int \beta_{u} S_{u}-\left(\mu_{u}+\alpha_{u}\right) d t \\
& \Leftrightarrow \ln I_{u} \quad=\int\left(\beta_{u} S_{u}-\left(\mu_{u}+\alpha_{u}\right)\right) d t+ \\
& \quad C, \\
& \quad \Leftrightarrow I_{u}(t) \\
& \quad=e^{\int\left(\beta_{u} S_{u}-\left(\mu_{u}+\alpha_{u}\right)\right) d t+C}, \\
& \quad \Leftrightarrow I_{u}(t) \\
& \quad=e^{\int\left(\beta_{u} S_{u}-\left(\mu_{u}+\alpha_{u}\right)\right) d t} e^{c}, \\
& \quad \Leftrightarrow I_{u}(t) \\
& \quad=C \cdot e^{\int\left(\beta_{u} S_{u}-\left(\mu_{u}+\alpha_{u}\right)\right) d t},
\end{aligned}
$$

titik ekuilibriumnya. Untuk menentukan nilai eigen bisa digunakan Kriteria RouthHurwitz. Selanjutnya dianalisis perilaku penularan virus H5N1 dengan simulasi numerik. Simulasi dilakukan dengan mensubtitusikan parameter-parameter yang diperoleh berdasarkan asumsi-asumsi yang telah dibuat. Untuk mempermudah menganalisis data, simulasi dilakukan dengan bantuan program Matlab. Hasil dari simulasi ini berupa grafik solusi yang menggambarkan perilaku model penularan virus $\mathrm{H} 5 \mathrm{~N} 1$ dalam keadaan sebenarnya.

dengan syarat awal $I_{u}(0)=\left(I_{u}\right)_{0}>0=C$ maka :

$$
\begin{aligned}
\Leftrightarrow I_{u}(t) & =\left(I_{u}\right)_{0} \cdot e^{\int\left(\beta_{u} s_{u}-\left(\mu_{u}+\alpha_{u}\right)\right) d t} \\
& >0 \text { untuk semua } t>0 .
\end{aligned}
$$

Andaikan solusi pertama pada Sistem (4.1) memenuhi $S_{u}(t) \leq 0$. Dipilih $t_{0}$ adalah titik awal pada sumbu $t$ yang menyebabkan $S_{u}(t)=0$. Pada saat $S_{u}(t)=0, \quad$ dari persamaan pertama pada Sistem (4.1) didapatkan $\left.\frac{d S_{u}}{d t}\right|_{t=t_{0}}=K_{u}>0$. Untuk titik $t$ yang dekat dengan $t_{0}$ dimana $t<t_{0}$ pasti ada $S_{u}(t)<0$, hal ini kontradiksi dengan pengandaian bahwa solusi Sistem dari (4.1) yaitu $S_{u}(t) \leq 0$. Oleh karena itu $S_{u}(t)>0$. Jadi solusi Sistem (4.1) yang memenuhi kondisi awal $S_{u}(0)=\left(S_{u}\right)_{0}>0, I_{u}(0)=$ $\left(I_{u}\right)_{0}>0$ bernilai positif.

Selanjutnya, akan dibahas bahwa semua solusi dari Sistem (4.1) akan berada pada daerah penyelesaian :

\section{Teorema 4.1.2}

$$
\begin{aligned}
& \varphi=\left\{\left(S_{u}, I_{u}\right) \in R_{+0}^{2} \mid S_{u}+I_{u} \leq\right. \\
& \left.\dot{N}_{u} \leq 1\right\}, \forall S_{u}, I_{u} \geq 0 .
\end{aligned}
$$

Pada saat $t \rightarrow \infty$, semua solusi pada Sistem (4.1) akan berada pada :

$$
\begin{aligned}
& \varphi=\left\{\left(S_{u}, I_{u}\right) \in R_{+0}^{2} \mid S_{u}+I_{u} \leq\right. \\
& \left.\dot{N}_{u} \leq 1\right\}, \forall S_{u}, I_{u} \geq 0 .
\end{aligned}
$$

\section{Lemma 4.1.3}

Himpunan $R_{+0}^{2}=\left\{\left(S_{u}, I_{u}\right): S_{u} \geq 0, I_{u} \geq 0\right\}$ merupakan himpunan invarian positif terhadap Sistem (4.1). 


\section{Bukti :}

Akan dibuktikan bahwa himpunan $R_{+0}^{2}$ merupakan himpunan invarian postif terhadap Sistem (4.1) artinya jika untuk sebarang syarat awal $x_{0}=\left(S_{u_{0}}, I_{u_{0}}\right) \in R_{+0}^{2}$ maka solusi Sistem (4.1) yaitu $x(t)=$ $\left(S_{u}(t), I_{u}(t)\right)$ dengan syarat $x(t)$ tersebut $\in$ $R_{+0}^{2}$ untuk $t \geq 0$. Dari persamaan (4.1) diperoleh :

i. Pada saat $S_{u_{0}}=0$, maka $\left.\frac{d S_{u}}{d t}\right|_{S_{u_{0}}=0}=$ $K_{u} \geq 0$. Oleh karena itu solusi $S_{u}(t) \geq 0$ dengan syarat $K_{u} \geq 0$.

ii. Pada saat $I_{u_{0}}=0$, maka $\left.\frac{d I_{u}}{d t}\right|_{I_{u_{0}=0}}=$ 0 , itu artinya $I_{u}(t)=0$ untuk $I_{u_{0}}=0$, telah dibuktikan pada Lemma 4.1 bahwa untuk $I_{u_{0}}>0$ maka $I_{u}(t)>0$. Oleh karena itu $I_{u}(t) \geq 0$, untuk syarat awal $I_{u_{0}} \geq 0$. Berdasarkan penjabaran tersebut di atas dapat disimpulkan bahwa dengan syarat awal $S_{u_{0}} \geq 0$ dan $I_{u_{0}} \geq 0$ maka akan didapatkan solusi Sistem (4.1) yaitu $S_{u}(t) \geq 0$ dan $I_{u}(t) \geq 0$. Dengan demikian terbukti bahwa $R_{+0}^{2}$ merupakan himpunan invarian positif.

\section{Eksistensi dan Kestabilan Titik Ekuilibrium}

Berikut ini akan dicari titik ekuilibrium pada Sistem (4.1). Diperhatikan Sistem (4.1), lebih lanjut didefinisikan untuk fungsi-fungsi sebagai berikut :

$$
\begin{aligned}
& f_{1}\left(S_{u}, I_{u}\right)=K_{u}-\left(\beta_{u} I_{u}+\right. \\
& \left.\mu_{u}\right) S_{u} \\
& f_{2}\left(S_{u}, I_{u}\right)=\beta_{u} I_{u} S_{u}-\left(\mu_{u}+\right. \\
& \left.\alpha_{u}\right) I_{u}
\end{aligned}
$$

$\operatorname{dan} \mathbf{f}\left(S_{u}, I_{u}\right)=\left(f_{1}, f_{2}\right)^{T}$.

\section{Lemma 4.1.4}

Diberikan $R_{0}=\frac{\beta_{u}}{\mu_{u}}$,

i. Jika $R_{0}<1$, maka Sistem (4.1) mempunyai dua titik ekuilibrium yaitu titik ekuilibrium bebas infeksi dari virus $\mathrm{H} 5 \mathrm{~N} 1$ dengan $E_{0}=(0,0)$ dan $E_{1}=\left(\frac{K_{u}}{\mu_{u}}, 0\right)$. ii. Jika $R_{0}>1$, maka Sistem (4.1) mempunyai dua titik ekuilibrium yaitu titik ekuilibrium bebas infeksi dari virus H5N1 dengan $E_{1}=\left(\frac{K_{u}}{\mu_{u}}, 0\right)$ dan titik ekuilibrium endemik yang berarti virus $\mathrm{H} 5 \mathrm{~N} 1$ masih terus ada dengan $E_{2}^{+}=\left(S_{u}^{*}, I_{u}^{*}\right)$ dimana $S_{u}^{*}=$ $\frac{\mu_{u}+\alpha_{u}}{\beta_{u}} \operatorname{dan} I_{u}^{*}=\frac{K_{u}}{\left(\mu_{u}+\alpha_{u}\right)}-\frac{\mu_{u}}{\beta_{u}}$.

Berikut ini akan dianalisis kestabilan titik ekuilibrium dari Sistem (4.1) yang berdasarkan nilai eigen matriks Jacobian untuk fungsi (4.3) sampai dengan (4.4).

\section{Lemma 4.1.5}

Matriks Jacobian fungsi $\mathbf{f}=\left(f_{1}, f_{2}\right)^{T}$ yang didefinisikan pada (4.3) - (4.4) di $\left(S_{u}, I_{u}\right)$ adalah $\quad: D \mathbf{f}\left(S_{u}, I_{u}\right)=$ $\left[\begin{array}{cc}\beta_{u} I_{u}+\mu_{u} & -\beta_{u} S_{u} \\ \beta_{u} I_{u} & -\left(\mu_{u}+\alpha_{u}\right)\end{array}\right]$.

\section{Bukti :}

Karena :

$$
\begin{gathered}
\frac{\partial f_{1}}{\partial S_{u}}=-\left(\beta_{u} I_{u}+\mu_{u}\right), \\
\frac{\partial f_{1}}{\partial I_{u}}=-\beta_{u} S_{u} \\
\frac{\partial f_{2}}{\partial S_{u}}=\beta_{u} I_{u}, \\
\frac{\partial f_{2}}{\partial I_{u}}=-\left(\mu_{u}+\alpha_{u}\right) .
\end{gathered}
$$

Maka diperoleh matriks Jacobian untuk fungsi $\mathbf{f}=\left(f_{1}, f_{2}\right)^{T} \quad$ yang didefiniskan pada

(4.3) - (4.4) di $\left(S_{u}, I_{u}\right)$ adalah :

$$
\begin{aligned}
& D \mathbf{f}\left(S_{u}, I_{u}\right) \\
& =\left[\begin{array}{ll}
\frac{\partial f_{1}}{\partial S_{u}}\left(S_{u}, I_{u}\right) & \frac{\partial f_{1}}{\partial I_{u}}\left(S_{u}, I_{u}\right) \\
\frac{\partial f_{2}}{\partial S_{u}}\left(S_{u}, I_{u}\right) & \frac{\partial f_{2}}{\partial S_{u}}\left(S_{u}, I_{u}\right)
\end{array}\right] .
\end{aligned}
$$

atau :

$$
\left[\begin{array}{cc}
D \mathbf{f}\left(S_{u}, I_{u}\right) & = \\
-\left(\beta_{u} I_{u}+\mu_{u}\right) & -\beta_{u} S_{u} \\
\beta_{u} I_{u} & -\left(\mu_{u}+\alpha_{u}\right)
\end{array}\right] .
$$

Pada Teorema berikut ini akan dibahas mengenai kestabilan titik ekuilibrium bebas infeksi dari virus $\mathrm{H} 5 \mathrm{~N} 1$ yaitu $E_{0}=(0,0)$ dan $E_{1}=\left(\frac{K_{u}}{\mu_{u}}, 0\right)$. 


\section{Teorema 4.1.6}

Diberikan $R_{0}=\frac{\beta_{u}}{\mu_{u}}$.

1. Titik ekuilibrium $E_{0}=(0,0)$ merupakan titik ekuilibrium yang stabil asimtotik lokal.

2. Jika $R_{0}<1$ dan $R_{0}>1$ maka titik ekuilibrium bebas infeksi virus $\mathrm{H} 5 \mathrm{NI}$ yaitu $E_{1}=\left(\frac{K_{u}}{\mu_{u}}, 0\right)$ stabil asimtotik lokal.

Berikut ini akan dibahas kestabilan titik ekuilibrium endemik $E_{2}^{+}=\left(S_{u}^{*}, I_{u}^{*}\right)$.

\section{Teorema 4.1.7}

Jika $R_{0}>1$ maka titik ekuilibrium endemik $E_{2}^{+}=\left(S_{u}^{*}, I_{u}^{*}\right)$ adalah fokus stabil.

berikut ini akan diberikan teorema yang membahas tentang kestabilan global titik ekuilibrium bebas infeksi $E_{1}=\left(\frac{K_{u}}{\mu_{u}}, 0\right)$.

\section{Teorema 4.1.8}

Jika $R_{0}<1$ maka titik ekuilibrium bebas infeksi $E_{1}=\left(\frac{K_{u}}{\mu_{u}}, 0\right)$ pada Sistem (4.1) stabil asimtotik global.

\section{Simulasi Numerik}

Berikut ini diberikan ilustrasi perilaku dari populasi individu unggas yang termasuk dalam kelas rentan dan populasi individu unggas yang masuk ke dalam kelas terinfeksi oleh virus $\mathrm{H} 5 \mathrm{~N} 1$ dalam ukuran proporsi.

1) Perilaku populasi unggas dengan $\boldsymbol{R}_{\mathbf{0}}<1$.

Berikut ini akan dikaji simulasi penyebaran virus $\mathrm{H} 5 \mathrm{~N} 1$ pada populasi unggas untuk kasus bebas dari virus H5N1. Teorema 4.8 telah mengkaji secara analitis bahwa titik ekuilibrium $E_{1}=\left(\frac{K_{u}}{\mu_{u}}, 0\right)$ stabil asimtotik global jika $R_{0}<1$. Jika diberikan syarat awal $\left(S_{u_{0}}, I_{u_{0}}\right)=(100,150)$ dan diambil nilai-nilai parameter (Smith, J.O., 2003) yang memenuhi kondisi $R_{0}<1$ yaitu $K_{u}=0,15 ; \beta_{u}=0,025 ; \mu_{u}=0,03 ;$ dan $\alpha_{u}=0,1$ maka diperoleh $R_{0}=\frac{\beta_{u}}{\mu_{u}}=$ $0,833<1$ dan titik ekuilibrium untuk bebas dari virus $\mathrm{H} 5 \mathrm{~N} 1$ yaitu $E_{1}=(5,0)$. Berikut ini diberikan grafik penyelesaian $S_{u}(t)$ dan $I_{u}(t)$ terhadap waktu yang menyatakan kepadatan populasi dari individu unggas yang rentan, dan kepadatan individu unggas yang terinfeksi dari virus H5N1.

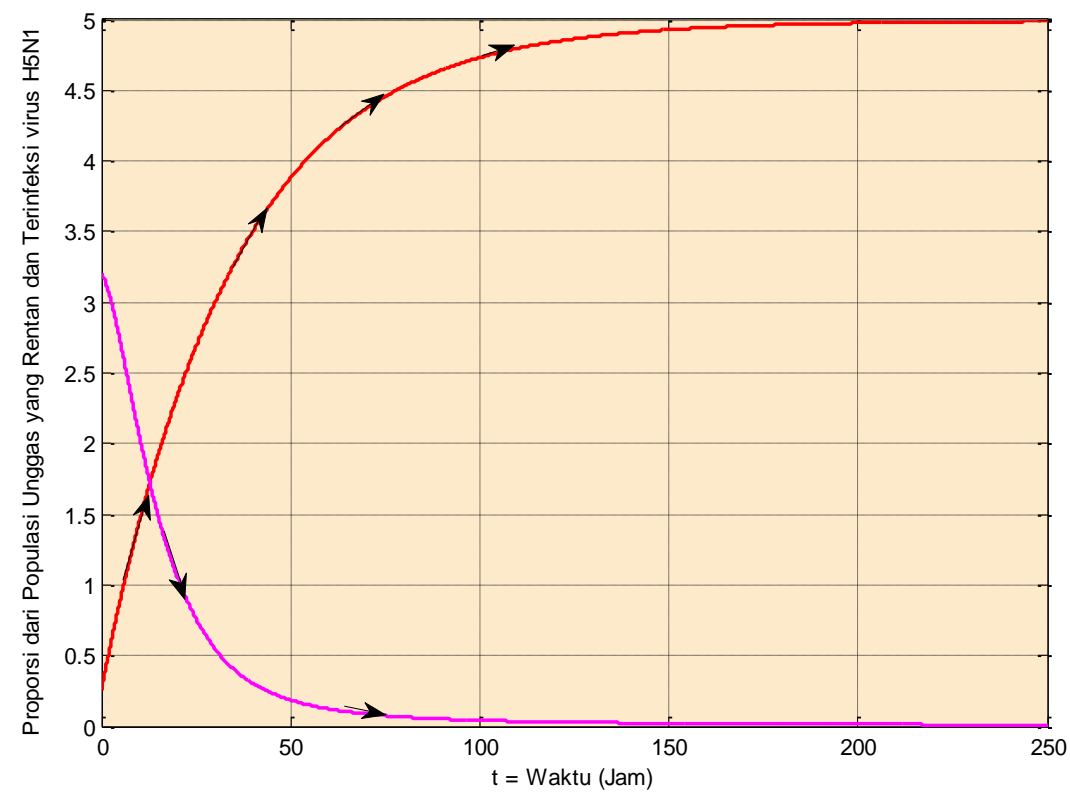


Gambar 1 Grafik Penyelesaian $S_{u}(t)$ yang menyatakan proporsi dari populasi unggas yang rentan dan $I_{u}(t)$ yang menyatakan proporsi dari populasi unggas yang terinfeksi dari virus $\mathrm{H} 5 \mathrm{~N} 1$ terhadap waktu.

Berdasarkan gambar 1 di atas terlihat bahwa untuk syarat awal $\left(S_{u}(0), I_{u}(0)\right)=$ $(0.38 ; 3.21)$, maka grafik penyelesaian $S_{u}(t)$ dan $I_{u}(t)$ menuju titik ekuilibrium bebas penyakit $E_{1}=(5,0)$.

2) Perilaku Populasi Unggas dengan $\boldsymbol{R}_{\mathbf{0}}>1$.

Berdasarkan Teorema 4.7 jika $R_{0}>1$ maka titik ekuilibrium endemik $E_{2}^{+}=\left(S_{u}^{*}, I_{u}^{*}\right)$ adalah stabil. Untuk itu diambil parameterparameter (Smith, J.O., 2003) yang

memenuhi kondisi $R_{0}>1$ yaitu $K_{u}=0,50$; $\beta_{u}=0,3 ; \mu_{u}=0,013 ;$ dan $\alpha_{u}=0,41$. Berdasarkan nilai parameter tersebut diperoleh $R_{0}=\frac{\beta_{u}}{\mu_{u}}=23,07>1$ dan titik ekuilibrium endemik yaitu $E_{2}^{+}=\left(S_{u}^{*}, I_{u}^{*}\right)=$ $(1.141 ; 1.139)$.

Berikut ini diberikan grafik penyelesaian $S_{u}(t)$ dan $I_{u}(t)$ terhadap waktu yang menyatakan proporsi dari populasi unggas yang rentan dan populasi unggas yang terinfeksi dari virus H5N1.

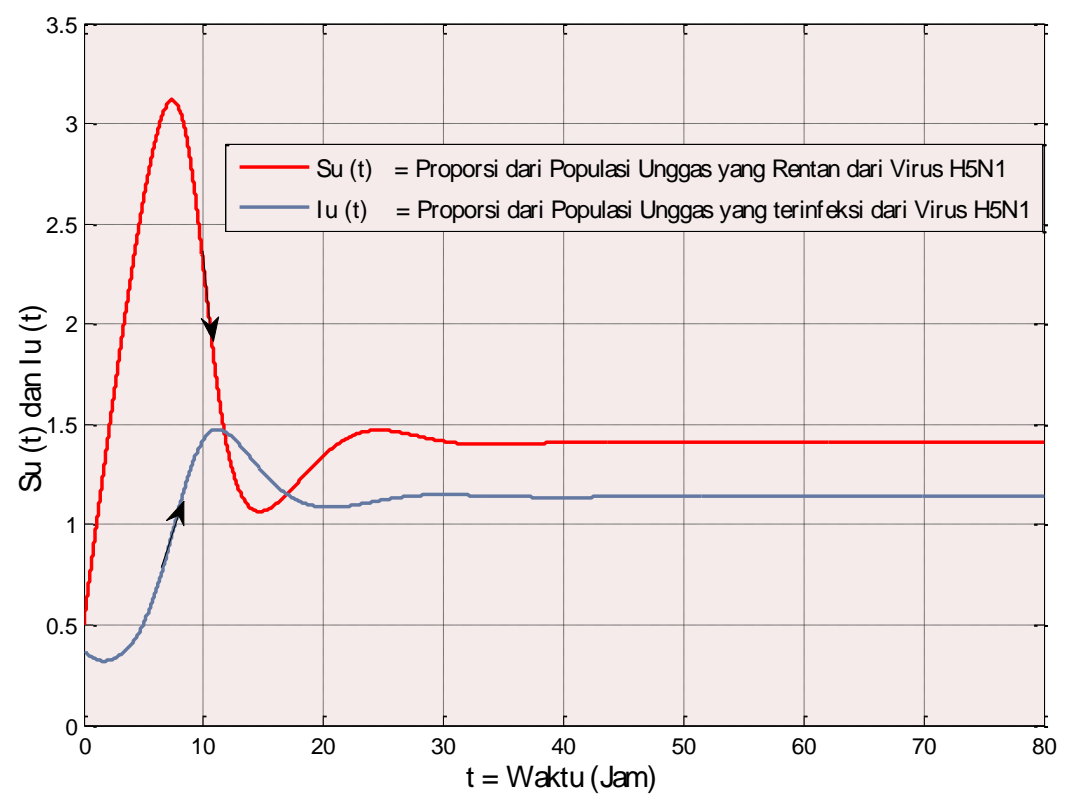

Gambar 4.6 Grafik penyelesaian

$S_{u}(t)$ dan $I_{u}(t)$ terhadap waktu Gambar 4.6 adalah grafik penyelesaian $S_{u}(t)$ dan $I_{u}(t)$ terhadap waktu pada nilai awal $\left(S_{u}(0), I_{u}(0)\right)=(0.5,0.38)$ dan terlihat bahwa penyelesaian menuju titik ekuilibrium endemik yaitu $E_{2}^{+}=\left(S_{u}^{*}, I_{u}^{*}\right)=$
$(1.41 ; 1.139)$. Hal ini berarti populasi unggas yang rentan tidak akan bebas dari virus H5N1 selamanya. Berikut ini diberikan potret fase penyelesaian $S_{u}(t)$ dan $I_{u}(t)$ yang menyatakan proporsi dari populasi unggas yang rentan dan proporsi dari populasi unggas yang terinfeksi Virus H5N1. 


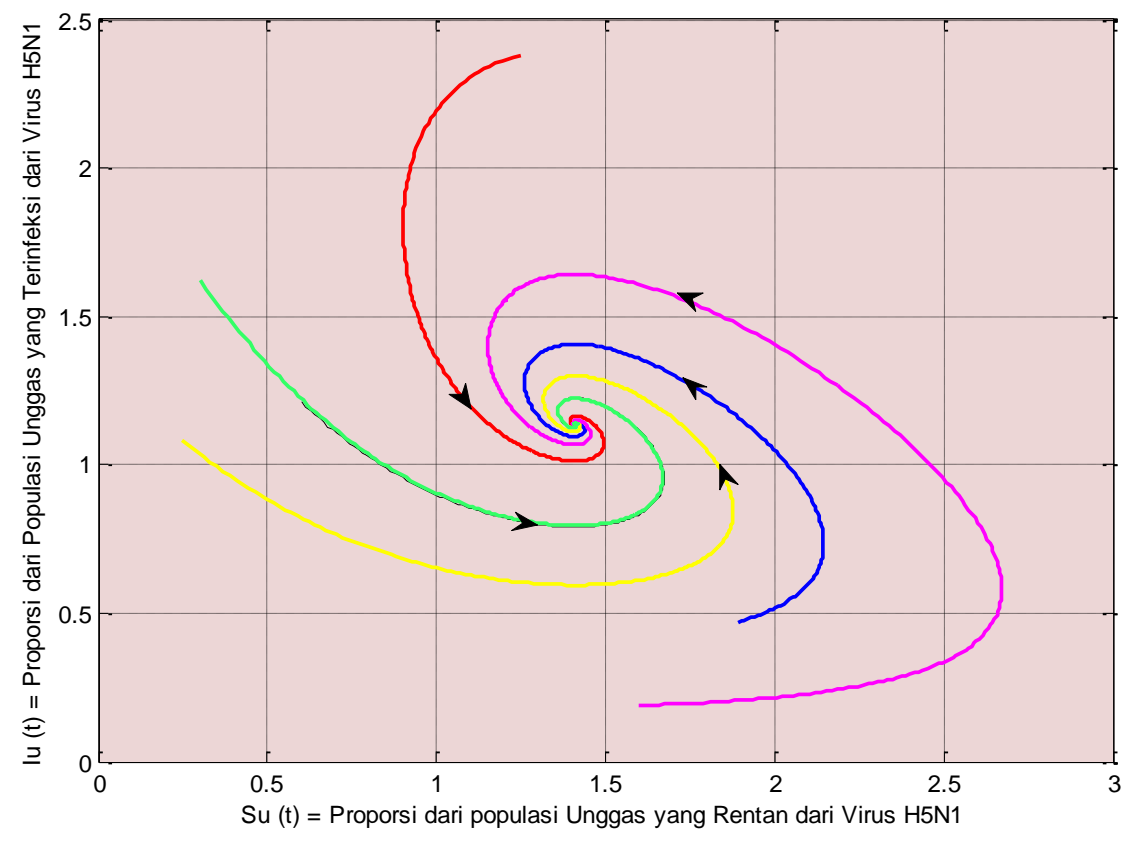

4.9. Proyeksi potret fase untuk bidang $S_{u}(t)$ dan $I_{u}(t)$

Gambar

Dari gambar 4.9 terlihat bahwa setiap potret fase (trayektori) untuk penyelesaian $S_{u}(t)$ dan $I_{u}(t)$ dalam beberapa pengambilan nilai awal yaitu $\left(S_{u}^{*}, I_{u}^{*}\right)=$ $(1.25,2.38),(0.60,1.21),(1.89,0.47),(0.25,1.08)$ er menuju ke titik ekuilibrium $E_{2}^{+}=\left(S_{u}^{*}, I_{u}^{*}\right)=$ $(1.41 ; 1.139)$. Hal ini menunjukkan bahwa individu unggas yang rentan dan individu unggas yang terinfeksi dari Virus H5N1 akan tetap ada dan hidup berdampingan di dalam suatu populasi dengan waktu yang cukup lama.

\section{SIMPULAN DAN SARAN Simpulan}

Dari analisa yang dilakukan pada bab sebelumnya, diperoleh kesimpulan bahwa model SI adalah model yang mendekati atau memenuhi fakta-fakta dan asumsi-asumsi dalam kasus epidemi penularan virus H5N1 pada populasi unggas. Bentuk Persamaan model matematika dari penyebaran virus H5N1 pada populasi unggas adalah sebagai berikut :

$$
\begin{aligned}
& \frac{d S_{u}}{d t}=K_{u}-\left(\beta_{u} I_{u}+\mu_{u}\right) S_{u} \\
& \frac{d I_{u}}{d t}=\beta_{u} I_{u} S_{u}-\left(\mu_{u}+\alpha_{u}\right) I_{u} .
\end{aligned}
$$

yang rentan dan $I_{u}$ menyatakan kepadatan unggas yang terinfeksi virus H5N1. Setelah dilakukan analisis terhadap sistem penyebaran virus H5N1 maka diperoleh domain Sistem dapat dibatasi pada daerah :

$$
\begin{gathered}
\varphi=\left\{\left(S_{u}, I_{u}\right) \in R_{+0}^{2} \mid S_{u}+I_{u} \leq \dot{N}_{u} \leq 1\right\}, \\
\forall S_{u}, I_{u} \geq 0
\end{gathered}
$$

Selanjutnya dari analisis eksistensi dan kestabilan titik ekuilibrium diperoleh bahwa:

1. Diberikan $R_{0}=\frac{\beta_{u}}{\mu_{u}}$,

a. Jika $R_{0}<1$, maka Sistem (4.1) mempunyai dua titik ekuilibrium yaitu titik ekuilibrium bebas infeksi dari virus $\mathrm{H} 5 \mathrm{~N} 1$ dengan $E_{0}=(0,0)$ dan $E_{1}=\left(\frac{K_{u}}{\mu_{u}}, 0\right)$.

b. Jika $R_{0}>1$, maka Sistem (4.1) mempunyai dua titik ekuilibrium yaitu titik ekuilibrium bebas infeksi 
dari virus H5N1 dengan $E_{1}=\left(\frac{K_{u}}{\mu_{u}}, 0\right)$ dan titik ekuilibrium endemik yang berarti virus $\mathrm{H} 5 \mathrm{~N} 1$ masih terus ada dengan $E_{2}^{+}=\left(S_{u}^{*}, I_{u}^{*}\right)$ dimana $S_{u}^{*}=$ $\frac{\mu_{u}+\alpha_{u}}{\beta_{u}}$ dan $I_{u}^{*}=\frac{K_{u}}{\left(\mu_{u}+\alpha_{u}\right)}-\frac{\mu_{u}}{\beta_{u}}$.

Titik $E_{2}^{+}=\left(S_{u}^{*}, I_{u}^{*}\right)$ menyatakan bahwa jika hasil kali laju kelahiran dengan laju kontak unggas yang rentan dengan unggas yang terinfeksi virus H5N1 lebih besar dari hasil kali laju efek naiknya angka kepadatan populasi unggas yang rentan dengan jumlah laju kematian karena unggas terinfeksi virus $\mathrm{H} 5 \mathrm{~N} 1$ maka akan terjadi endemik atau dengan kata lain terjadi penyebaran virus $\mathrm{H} 5 \mathrm{~N} 1$.

2. Jika $R_{0}<1$ maka titik ekuilibrium bebas infeksi $E_{1}=\left(\frac{K_{u}}{\mu_{u}}, 0\right)$ pada Sistem (4.1) stabil asimtotik global. Interpretasi dari hal tersebut adalah jika :

a. Besar hasil kali laju kelahiran dengan laju kontak populasi unggas yang rentan dengan unggas yang terinfeksi lebih kecil atau sama dengan hasil kali pengaruh naiknya angka kepadatan populasi unggas yang rentan dengan jumlah laju kematian akibat oleh infeksi virus H5N1.

b. Pada awal waktu berapapun, banyaknya kepadatan populasi unggas yang rentan dekat dengan $\frac{K_{u}}{\mu_{u}}$ dan banyaknya unggas yang terinfeksi virus $\mathrm{H} 5 \mathrm{~N} 1$ sangat sedikit, maka untuk waktu yang cukup lama tingkat kepadatan populasi unggas yang rentan mendekati $\frac{K_{u}}{\mu_{u}}$ sedangkan banyaknya populasi unggas yang terinfeksi virus $\mathrm{H} 5 \mathrm{~N} 1$ akan punah.

\section{Saran}

Karena berbagai keterbatasan, penulis menyadari bahwa penelitian ini masih banyak kekurangan, diantaranya adalah penulis hanya menganalisis kestabilan titik ekuilibrum endemik sebatas stabil asimtotik lokal saja. Penelitian ini dapat dilanjutkan dengan menyelidiki kestabilan global dari titik ekuilibrium endemik tersebut.

\section{DAFTAR PUSTAKA}

Aditama, 2004. Flu Burung di Manusia. Perhimpunan Dokter Paru Indonesia. Jakarta : Penerbit Universitas Indonesia.

Anton, H., 2004, Aljabar Linear Elementer edisi kedelapan. Jakarta : Erlangga.

Asmara, W. 2008. Peran Biologi Molekuler

Dalam Pengendalian Avian Influenza dan Flu Burung. Fakultas Kedokteran Hewan Universitas Gadjah Mada.

Derouich, M. \& Boutayeb. 2008. An Avian Influenza Mathematical Model. Applied Mathematical Sciences. Vol II (36). Oudja : Faculte des Sciences.

Gantmacher, F.R., 1959, The Theory of Matrices, Chelsea Publishing Company, New York, N.Y.

Hanh, W., 1967, Stability of Motion, Springer-Verlag, Inc., New York.

Khalil, H.K., 2002, Nonlinear System (Third Edition), Prentice-Hall, Inc, New Jersey.

Luenberger, D.C., 1979, Introduction to Dynamic Systems, John Willey and Sons, Inc, United States.

Noviana P \& Kartono. 2008. Strategi Model Pengendalian Penyebaran Virus Influenza. Jurnal matematika FMIPA Universitas Diponegoro, Vol II ; 141-145.

Olsder, G.J., 1994, Mathematical Systems Theory, Delftse Uitgevers Matschappij b.v., Netherlands. 
Perko, L., 1993, Differential Equations and Dynamical System, SpringerVerlag, Inc., New York.

Radji, M. 2006. Avian Influenza A (H5N1) : Patogenesis, Pencegahan, dan penyebaran pada manusia. Majalah Ilmu Kefarmasian Vol III : 55-65.

Rahardjo, Y. 2004. Avian Influenza, Pencegahan, Pengendalian, dan Pemberantasannya. Jakarta : PT Gita Gallus Utama.

Siswanto, Supriyono, Wuryanto. 2013. Model Matematika penyebaran Flu Burung dari Unggas ke Manusia. Jurnal Matematika FMIPA UNNES Vol II.

Smith, James O. Lioyd, 2003, Curtailing transmission of severe acute respiratori syndrome within a community and its hospital, the royal society, diakses 25 September 2015.

Susanta, B., 1989, Pemodelan Matematis. Jakarta : Modul UT.

Tarumingkeng, R.C., 1994, Dinamika Populasi Kajian Ekologi Kuantitatif. Jakarta : Pustaka Sinar Harapan.

Wiggins, S., 1996, Introduction to Applied Nonlinear Dynamical System and Chaos, Springer-Verlag, Inc., New York. 